\title{
Aerococcus urinae: Intraspecies Genetic and Phenotypic Relatedness
}

\author{
JENS J. CHRISTENSEN, ${ }^{1 *}$ ANNE M. WHITNEY, ${ }^{2}$ LUCIA M. TEIXEIRA, ${ }^{3}$ ARNOLD G. STEIGERWALT, ${ }^{2}$ \\ RICHARD R. FACKLAM, ${ }^{4}$ BENT KORNER, ${ }^{5}$ AND DON J. BRENNER ${ }^{2}$ \\ Department of Clinical Microbiology, Herlev Hospital, DK-2730 Herlev, ${ }^{1}$ and Department of Clinical Microbiology, \\ Bispebjerg Hospital, DK-2400 Copenhagen, ${ }^{5}$ Denmark; Emerging Bacterial and Mycotic Diseases Branch, ${ }^{2}$ and \\ Respiratory Diseases Branch, ${ }^{4}$ Division of Bacterial and Mycotic Diseases, Centers for Disease Control \\ and Prevention, Atlanta, Georgia 30333; and Instituto de Microbiologia, Universidade Federal \\ do Rio de Janeiro, Rio de Janeiro 21941, Brazil ${ }^{3}$
}

\begin{abstract}
A number of Aerococcus-like organisms were recently recognized as human pathogens. Five Aerococcus-like strains were proposed as members of the new species Aerococcus urinae (with type strain E2 [= NCTC 12142]) on the basis of the results of a 16S rRNA sequence analysis. The intraspecies phenotypic and genetic relatedness of 22 selected $A$. urinae strains was investigated, and a hitherto unrecognized esculin hydrolysispositive biotype was identified. A total of 14 of the 15 more common esculin-negative strains exhibited very high DNA relatedness as determined by the hydroxyapatite method (the levels of relatedness were greater than $90 \%$ in 55 and $70^{\circ} \mathrm{C}$ reactions, with $1.5 \%$ or less divergence in related sequences). The DNA relatedness among the six esculin-positive strains was more heterogeneous, and two DNA hybridization subgroups were formed. Our results are compatible with the hypothesis that both biotypes are members of the single species $A$. urinae, which contains two or more genetic subspecies. The putative subspecies have not been formally proposed since they cannot be definitively differentiated. The inclusion of $A$. urinae in the genus Aerococcus is supported by the results of $16 \mathrm{~S}$ rRNA sequencing. The rRNA sequence data also is compatible with placing both biotypes in a single species.
\end{abstract}

Recently, some Aerococcus-like organisms were recognized and characterized as human pathogens (5-8). These bacteria were isolated from urine specimens from elderly patients suffering from urinary tract infections $(5,7)$ and from blood cultures taken from patients with endocarditis and urosepticemia $(6,8)$. The Aerococcus-like organisms were described by Aguirre and Collins as members of a new species of the genus Aerococcus, Aerococcus urinae, based on the results of a partial $16 \mathrm{~S}$ ribosomal nucleic acid sequence analysis (1). These authors sequenced short fragments of $16 \mathrm{~S}$ rRNA corresponding to $E$. coli $16 \mathrm{~S}$ positions 50 to 450 and 950 to $1210(1,4)$ that included four variable regions from five phenotypically identical Aerococcus-like strains, including type strain E2 (= NCTC 12142), and found that these fragments were $100 \%$ homologous. The sequence of 1,481 nucleotides of the $16 \mathrm{~S}$ rRNA of one representative strain (strain $\mathrm{E} 2^{\mathrm{T}}[\mathrm{T}=$ type strain]) was determined. The primary sequence of this organism was aligned and compared with the $16 \mathrm{~S}$ rRNA sequences of 28 reference strains, including Aerococcus viridans strains. The Aerococcus-like organism sequence exhibited $94.5 \%$ similarity to the $A$. viridans sequence, 91 to $92 \%$ similarity to the sequences of carnobacteria, enterococci, and vagococci, and 86 to $90 \%$ similarity to the sequences of members of other genera, including the genera Lactobacillus, Lactococcus, Leuconostoc, Pediococcus, and Streptococcus. The Aerococcus-like organisms could be differentiated phenotypically from $A$. viridans. Because of these findings, Aguirre and Collins concluded that the Aerococcus-like organisms represent a second line within the genus Aerococcus, which they described as the new species $A$. urinae (1).

During the last decade strains resembling the Danish $A$. urinae strains have been received for identification at the Cen-

* Corresponding author. Present address: Department of Clinical Microbiology, Århus University Hospital, Nørrebrogade 44, 8000 Århus C, Denmark. Phone: 458949 3527. Fax: 4589493540. ters for Disease Control and Prevention (CDC). Most of these strains were able to hydrolyze esculin, in contrast to the Danish isolates. The CDC and Danish A. urinae strains were tested to determine intraspecies relatedness by examining phenotypic characteristics, DNA relatedness, and partial $16 \mathrm{~S}$ ribosomal nucleic acid sequences. In this study the separation of these organisms from $A$. viridans and their relatedness to $A$. viridans were investigated in relation to the previous findings of Aguirre and Collins (1).

\section{MATERIALS AND METHODS}

Bacterial strains. The $22 \mathrm{~A}$. urinae strains included in the present study are listed in Table 1; 7 non-Danish strains were obtained from the culture collection of the Streptococcus Laboratory, CDC, Atlanta, Ga. In addition, the following strains were used in the DNA reassociation studies: $A$. viridans ATCC $11563^{\mathrm{T}}$, SS-930 (2), and 1679-93 and Pediococcus urinaeequi ATCC $29723^{\mathrm{T}}$

Phenotypic characterization of $A$. urinae strains. Phenotypic characteristics of strains were determined by conventional tests as described by Facklam and Elliott (13).

DNA reassociation studies. The strains used for DNA extraction were grown in 2 liters of Todd-Hewitt broth at $37^{\circ} \mathrm{C}$ for 18 to $20 \mathrm{~h}$ with gentle shaking. Cells were harvested by centrifugation and were resuspended in a solution containing $50 \mathrm{ml}$ of TS buffer ( $50 \mathrm{mM}$ Tris buffer [pH 8.0$]$ containing $12.5 \%$ sucrose), $10 \mathrm{ml}$ of a lysozyme solution ( $20 \mathrm{mg} / \mathrm{ml}$; Sigma Chemical Co., St. Louis, Mo.), and $1 \mathrm{ml}$ of mutanolysin $(2,000 \mathrm{U} / \mathrm{ml}$; Sigma Chemical Co. $)$. After $1 \mathrm{~h}$ of incubation at $37^{\circ} \mathrm{C}, 20 \mathrm{ml}$ of a $50 \mathrm{mM}$ EDTA solution and $0.33 \mathrm{ml}$ of a proteinase $\mathrm{K}$ solution ( $25 \mathrm{mg} / \mathrm{ml}$; Sigma Chemical Co.) were added, and the suspension was incubated for $1 \mathrm{~h}$ at $37^{\circ} \mathrm{C}$. Lysis was completed by adding $10 \mathrm{ml}$ of a $10 \%$ sodium dodecyl sulfate solution. The procedures used to purify DNA for determinations of DNA relatedness in free solution by the hydroxyapatite hybridization method have been described previously (3). The DNAs were labeled enzymatically in vitro with $\left[{ }^{32} \mathrm{P}\right] \mathrm{dCTP}$ by using a nick translation reagent kit (Gibco BRL Life Technologies, Inc., Gaithersburg, Md.) as directed by the manufacturer. DNA hybridization experiments were performed at $55^{\circ} \mathrm{C}$ for optimal DNA reassociation and at $70^{\circ} \mathrm{C}$ for stringent DNA reassociation. Levels of divergence within related sequences were determined by assuming that each $1{ }^{\circ} \mathrm{C}$ of DNA heteroduplex instability, compared with the melting temperature of the homologous DNA duplex, was caused by approximately $1 \%$ unpaired bases. Levels of divergence were calculated to the nearest $0.5 \%$.

PCR amplification of rDNA and 16S rDNA sequencing. Template DNAs for sequencing were prepared by enzymatic amplification of the $16 \mathrm{~S}$ rRNA genes of $A$. viridans ATCC $11563^{\mathrm{T}}$ and $A$. urinae $\mathrm{E} 2^{\mathrm{T}}, 1656-92, \mathrm{G} 1-84, \mathrm{~F} 1-84,998-93$, and 944-94. Modified versions of primers fd1 and rd1 $(11,20)$ were used in the PCR; 
TABLE 1. Strains of $A$. urinae examined in this study

\begin{tabular}{|c|c|c|}
\hline Strain & Source & Sender ${ }^{a}$ \\
\hline \multicolumn{3}{|l|}{ Danish strains } \\
\hline $\begin{array}{l}\mathrm{E} 2^{\mathrm{T}}\left(=\text { NCTC } 12142^{\mathrm{T}}\right. \\
\left.\quad=\text { NCFB } 2893^{\mathrm{T}}\right)\end{array}$ & Urine & Bispebjerg Hospital DCM \\
\hline G1-84 & Urine & Bispebjerg Hospital DCM \\
\hline F1-84 & Urine & Bispebjerg Hospital DCM \\
\hline R7-89 & Urine & Rigshospitalet DCM \\
\hline R8-89 & Urine & Rigshospitalet DCM \\
\hline Å11-89 & Urine & Ålborg Hospital DCM \\
\hline BBH-B $1-89$ & Blood & Bispebjerg Hospital DCM \\
\hline FH-B1-89 & Blood & Frederiksberg Hospital DCM \\
\hline HER-B1-92 & Blood & Herlev Hospital DCM \\
\hline HER-B2-93 & Blood & Herlev Hospital DCM \\
\hline HIL-B1-91 & Blood & Hillerod Hospital DCM \\
\hline ÅLB-B lb-93 & Heart valve & Ålborg Hospital DCM \\
\hline ÅLB-B $1 \mathrm{a}-93$ & Blood & Ålborg Hospital DCM \\
\hline ÅH-B2-94 & Blood & Århus Hospital DCM \\
\hline \multicolumn{3}{|l|}{ Non-Danish strains } \\
\hline $998-93$ & Urine & New York SHD \\
\hline $1656-92$ & Urine & New York SHD \\
\hline $1515-85$ & Urine & A. W. Sturm, The Netherlands \\
\hline $1871-94$ & Urine & New York SHD \\
\hline 944-94 & Urine & Ohio SHD \\
\hline $3352-95$ & Urine & $\begin{array}{l}\text { M. Lovgren, Edmonton, } \\
\text { Alberta, Canada }\end{array}$ \\
\hline $1667-95$ & Urine & $\begin{array}{l}\text { M. Lovgren, Edmonton, } \\
\text { Alberta, Canada }\end{array}$ \\
\hline
\end{tabular}

${ }^{a}$ DCM, Department of Clinical Microbiology; SHD, State Health Department.

the enzyme linker region was omitted from each primer. The PCR conditions used have been described previously (21). The DNA produced was purified from the reaction mixture by filtration through a Centricon column (Amicon, Beverly, Mass.) before sequencing. The $16 \mathrm{~S}$ ribosomal DNAs (rDNAs) were sequenced by using Amplitaq DNA polymerase (Perkin-Elmer Cetus, Norwalk, Conn.) and dye-labeled dideoxynucleotides (Applied Biosystems, Inc., Foster City, Calif.). The primer set used for sequencing was derived from the primer sets described by Stackebrandt and Charfreitag (18). The resulting DNA fragments were separated from the cycle sequencing reaction mixture by filtration through a Centrisep column (Princeton Separations, Adelphia, N.J.). The fragments were then resolved on $6 \%$ polyacrylamide gels containing $8 \mathrm{M}$ urea in an automated sequencer (model 373A; Applied Biosystems, Inc.), and data were collected and plotted on a Macintosh computer equipped with compatible software (Applied Biosystems, Inc.). The sequences were edited and analyzed by using DNASTAR software (DNASTAR, Inc., Madison, Wis.). The $16 \mathrm{~S}$ rDNA sequences used in a multiple-sequence alignment were retricved from GenBank and were aligned by using PILEUP from the Genetics Computer Group (12). PHYLIP version 3.51c (15) software was used to compute phylogenetic relationships based on a continuous stretch of 1,320 nucleotides of the $16 \mathrm{~S}$ rDNA. A similarity matrix was computed by the method described by Jukes and Cantor (16). A dendrogram was constructed by the neighbor-joining method described by Saitou and Nei (17). The designations and GenBank nucleotide sequence accession numbers for strains whose $16 \mathrm{~S}$ rRNA sequences were used to construct the dendrogram in Fig. 1 are shown in Table 2 .

\section{RESULTS}

All $22 A$. urinae strains were $\alpha$-hemolytic, gram-positive cocci that occurred predominantly in clumps. All of these strains gave positive reactions in the following tests: vancomycin sensitivity; production of leucine aminopeptidase; growth in the presence of $6.5 \% \mathrm{NaCl}$; growth at $45^{\circ} \mathrm{C}$; hippurate hydrolysis; and acid production from D-mannitol, D-sorbitol, and sucrose. All of the strains gave negative reactions in the following tests: catalase; motility; pigmentation; production of pyrrolidonyl aminopeptidase; gas production from MRS broth; bile-esculin; growth at $10^{\circ} \mathrm{C}$; deamination of arginine; production of urease; hydrolysis of starch; utilization of pyruvate; tellurite; litmus milk reaction; acetoin production; and acid production from L-arabinose, glycerol, inulin, lactose, melibi-
TABLE 2. Strain designations and GenBank accession numbers or references for $16 \mathrm{~S}$ rRNA gene sequences used to construct the dendrogram

\begin{tabular}{|c|c|c|}
\hline Organism & Strain & $\begin{array}{l}\text { Accession no. } \\
\text { or reference }\end{array}$ \\
\hline Aerococcus urinae & $\mathrm{E} 2^{\mathrm{T}}$ & M77819 \\
\hline Aerococcus urinae & F1-84 & U64456 \\
\hline Aerococcus urinae & G1-84 & U64457 \\
\hline Aerococcus urinae & $1656-92$ & U64458 \\
\hline Aerococcus urinae & $944-94$ & U64459 \\
\hline Aerococcus urinae & $998-93$ & U64460 \\
\hline Aerococcus viridans & ATCC 11563 & M58797 \\
\hline Bacillus anthracis & Storne & $\mathrm{X} 55059$ \\
\hline Bacillus cereus & NCDO 1771 & $\times 55060$ \\
\hline Bacillus subtilis & NCDO 1769 & X60646 \\
\hline Brochothrix campestris & ATCC 43754 & X56156 \\
\hline Brochothrix thermosphacta & NCDO 1676 & X56155 \\
\hline Camobacterium divergens & NCDO 2763 & X54270 \\
\hline Carnobacterium gallinarum & NCFB 2766 & X54269 \\
\hline Carnobacterium piscicola & NCDO 2762 & X54268 \\
\hline Gemella haemolysans & ATCC 10379 & L14326 \\
\hline Gemella morbillorum & ATCC 27824 & L14327 \\
\hline Helcococcus kunzii & NCFB 2900 & 9 \\
\hline Lactobacillus delbreuckii & DSM 20074 & M58814 \\
\hline Lactobacillus confusus & NCDO 5186 & $\mathrm{X} 52567$ \\
\hline Lactococcus gurvieae & NCDO 2155 & X54262 \\
\hline Lactococcus lactis & NCDO 2118 & $\mathrm{X} 54260$ \\
\hline Lactococcus raffinolactis & NCDO 617 & X54261 \\
\hline Leuconostoc mesenteroides & DSM 20343 & M23035 \\
\hline Listeria monocytogenes & ATCC 35152 & M58822 \\
\hline Pediococcus damnosus & NCDO 1832 & 10 \\
\hline Pediococcus parvulus & NCDO 1634 & 10 \\
\hline Pediococcus pentosaceus & DSM 20336 & 10 \\
\hline Pediococcus urinaeequi & NCDO 1636 & 10 \\
\hline Streptococcus mutans & NCTC 10499 & X58303 \\
\hline Streptococcus parasanguis & ATCC 15912 & X53652 \\
\hline Streptococcus pyogenes & NCDO 2381 & $\times 59029$ \\
\hline Streptococcus sanguis & NCTC 7863 & X53653 \\
\hline Vagococcus fluvialis & NCDO 2497 & $\mathrm{X} 54258$ \\
\hline Vagococcus salmoninarum & NCFB 2777 & X54272 \\
\hline
\end{tabular}

ose, raffinose, sorbose, and trehalose. On 5\% sucrose agar the strains were mucoid and nonadherent; in $5 \%$ sucrose broth they were not gelled or viscous, nor did they produce deposits. Acid was produced from maltose by four strains (one esculinpositive strain and three esculin-negative strains). Six isolates were esculin hydrolysis positive, which provided the basis for two biotypes. The esculin-negative biotype included all of the Danish strains and a single non-Danish strain, while the esculin-positive biotype contained only non-Danish isolates.

A. urinae $\mathrm{E} 2^{\mathrm{T}}, \mathrm{G} 1-84,1656-92$, and $998-93$ were radiolabeled for use in DNA reassociation experiments (Table 3). Strains $\mathrm{E} 2^{\mathrm{T}}$ and $\mathrm{G} 1-84$ were very closely related; these organisms exhibited $99 \%$ relatedness at $55^{\circ} \mathrm{C}$ as well as at $70^{\circ} \mathrm{C}$, and the level of divergence in related DNA sequences was less than $0.5 \%$. Labeled DNAs from these two esculin-negative strains exhibited a median level of relatedness of $96 \%$ (range, 90 to $99 \%$ ) to 12 other esculin-negative $A$. urinae isolates in reactions at $55^{\circ} \mathrm{C}$; the levels of divergence were between 0 and $2.0 \%$. In reactions at $70^{\circ} \mathrm{C}$ the median level of relatedness was $98 \%$ (range, 92 to $100 \%$ ). Strain $998-93$, although phenotypically identical to the labeled strains, exhibited relative binding ratios (RBR) of 66 and $61 \%$ at the optimal and stringent temperatures, respectively, and a level of divergence of $5.5 \%$. In the reciprocal reactions, labeled DNA from strain 998-93 exhibited higher levels of relatedness to $E 2^{\mathrm{T}}$; the RBR were 83 and $69 \%$ at the optimal and stringent incubation temperatures, 
TABLE 3. Intraspecies DNA relatedness of $A$. urinae strains

\begin{tabular}{|c|c|c|c|c|c|c|c|c|c|c|c|c|}
\hline \multirow{3}{*}{$\begin{array}{c}\text { Source of } \\
\text { unlabeled DNA }\end{array}$} & \multicolumn{12}{|c|}{ Source of labeled DNA ${ }^{a}$} \\
\hline & \multicolumn{3}{|c|}{ Strain $\mathrm{E} 2^{\mathrm{T}}$} & \multicolumn{3}{|c|}{ Strain G1-84 } & \multicolumn{3}{|c|}{ Strain $1656-92$} & \multicolumn{3}{|c|}{ Strain 998-93 } \\
\hline & $\begin{array}{c}\mathrm{RBR} \text { at } \\
55^{\circ} \mathrm{C}(\%)\end{array}$ & $\begin{array}{c}\% \\
\text { Diver- } \\
\text { gence }\end{array}$ & $\begin{array}{l}\mathrm{RBR} \text { at } \\
70^{\circ} \mathrm{C}(\%)\end{array}$ & $\begin{array}{c}\mathrm{RBR} \text { at } \\
55^{\circ} \mathrm{C}(\%)\end{array}$ & $\begin{array}{c}\% \\
\text { Diver- } \\
\text { gence }\end{array}$ & $\begin{array}{l}\text { RBR at } \\
70^{\circ} \mathrm{C}(\%)\end{array}$ & $\begin{array}{l}\mathrm{RBR} \text { at } \\
55^{\circ} \mathrm{C}(\%)\end{array}$ & $\begin{array}{c}\% \\
\text { Diver- } \\
\text { gence }\end{array}$ & $\begin{array}{c}\text { RBR at } \\
70^{\circ} \mathrm{C}(\%)\end{array}$ & $\begin{array}{l}\mathrm{RBR} \text { at } \\
55^{\circ} \mathrm{C}(\%)\end{array}$ & $\begin{array}{c}\% \\
\text { Diver- } \\
\text { gence }\end{array}$ & $\begin{array}{c}\mathrm{RBR} \text { at } \\
70^{\circ} \mathrm{C}(\%)\end{array}$ \\
\hline \multicolumn{13}{|c|}{$\begin{array}{l}\text { Biotype } 1 \text { strains } \\
\text { (esculin negative) }\end{array}$} \\
\hline $\mathrm{E} 2^{\mathrm{T}}$ & 100 & 0.0 & 100 & & & & 63 & 5.0 & 55 & 83 & 4.5 & 69 \\
\hline G1-84 & 99 & 0.0 & 99 & 100 & 0.0 & 100 & 68 & 5.5 & 57 & & & \\
\hline FH-B1-89 & 99 & 0.5 & 99 & 98 & 1.0 & 99 & & & & & & \\
\hline F1-84 & & & & 98 & 1.5 & 100 & & & & & & \\
\hline BBH-B1-89 & & & & 99 & 2.0 & 100 & & & & & & \\
\hline HER-B1-92 & & & & 97 & 1.0 & 97 & & & & & & \\
\hline HER-B2-93 & & & & 96 & 1.5 & 98 & & & & & & \\
\hline HIL-B1-91 & & & & 91 & 1.0 & 95 & & & & & & \\
\hline ÅLB-B1b-93 & & & & 94 & 1.0 & 99 & & & & & & \\
\hline ÅLB-B1a-93 & & & & 96 & 1.0 & 98 & & & & & & \\
\hline ÅRH-B2-94 & & & & 90 & 1.0 & 92 & & & & & & \\
\hline R7-89 & 97 & 0.0 & 99 & & & & & & & & & \\
\hline $\mathrm{R} 8-89$ & 93 & 0.0 & 92 & & & & & & & & & \\
\hline$\AA ̊ \AA 11-89$ & 90 & 0.0 & 94 & & & & & & & & & \\
\hline $998-93$ & 66 & 5.5 & 61 & & & & 79 & 4.0 & 64 & 100 & 0.0 & 100 \\
\hline \multicolumn{13}{|c|}{$\begin{array}{l}\text { Biotype } 2 \text { strains } \\
\text { (esculin positive) }\end{array}$} \\
\hline $1656-92$ & & & & 74 & 6.0 & 62 & 100 & 0.0 & 100 & 78 & 4.0 & 67 \\
\hline $1515-85$ & & & & 81 & 6.0 & 68 & 73 & 5.5 & 61 & & & \\
\hline $3352-95$ & 69 & 5.5 & 60 & & & & 70 & 5.0 & 57 & & & \\
\hline $944-94$ & & & & & & & 93 & 3.0 & 93 & & & \\
\hline $1871-94$ & & & & & & & 93 & 3.0 & 94 & & & \\
\hline $1667-95$ & 64 & 4.5 & 59 & & & & 96 & 0.0 & 97 & & & \\
\hline
\end{tabular}

"The values are the averages of the values from two experiments. Before normalization to $100 \%$ the levels of DNA bound to hydroxyapatite in homologous reactions were 54 to $78 \%$. The levels of labeled DNA that bound to hydroxyapatite in control reaction mixtures that did not contain unlabeled DNA were 0.5 to $3.5 \%$ at $55^{\circ} \mathrm{C}$ and 0.5 to $3.0 \%$ at $70{ }^{\circ} \mathrm{C}$; these control values were subtracted from all reassociation reaction values before normalization.

respectively, and the level of divergence was $4.5 \%$. The median levels of relatedness of strains $E 2^{\mathrm{T}}$ and G1-84 to four of the esculin-positive $A$. urinae isolates were $72 \%$ (range, 64 to $81 \%$ ) at $55^{\circ} \mathrm{C}$ and $62 \%$ (range, 59 to $68 \%$ ) at $70^{\circ} \mathrm{C}$, with levels of divergence between 4.5 and $6.0 \%$. Labeled DNA from esculinpositive strain 1656-93 was highly related to DNAs from three of the other five esculin-positive strains, with RBR greater than $93 \%$ and levels of divergence of $\leq 3.0 \%$, whereas for two esculin-positive strains the RBR were lower and the level of divergence was $5.5 \%$ and thus the values were comparable to the values obtained when these strains were compared to E2 ${ }^{\mathrm{T}}$ and G1-84. Thus, all of the esculin-negative strains except strain 998-93 comprised a very homogeneous group, and these strains were closely related to, but slightly genotypically different from, the esculin-positive strains. Strain 998-93 was also slightly genotypically different from esculin-negative strain $E 2^{\mathrm{T}}$ and esculin-positive strain 1656-92. Strain E2 ${ }^{\mathrm{T}}$ exhibited RBR of 10 to $14 \%$ with the $A$. viridans strains and $P$. urinaeequi at $55^{\circ} \mathrm{C}$.

16S rDNA sequences of $A$. urinae $\mathrm{E}^{\mathrm{T}}$, 1656-92, G1-84, F1-84, 944-94, 998-93, A. viridans ATCC $11563^{\mathrm{T}}$, and $P$. urinaeequi ATCC $29723^{\mathrm{T}}$ were determined. The $A$. urinae strains exhibited 98.2 to $99.3 \%$ similarity over 1,320 bases (Table 4 ). There were 7 to 10 nucleotide differences between the esculin-

TABLE 4. Levels of similarity based on a comparison of 1,320 nucleotides of the 16S rRNA genes of $A$. viridans, A. urinae, P. uninaeequi, and Pediococcus damnosus ${ }^{u}$

\begin{tabular}{|c|c|c|c|c|c|c|c|c|c|}
\hline \multirow[b]{2}{*}{ Taxon } & \multicolumn{9}{|c|}{$\%$ Similarity } \\
\hline & A. viridans & $\begin{array}{l}\text { A. urinae } \\
\text { E2 }^{\mathrm{T}}\end{array}$ & $\begin{array}{c}\text { A. urinae } \\
\text { F1-84 }\end{array}$ & $\begin{array}{l}\text { A. urinae } \\
1656-92\end{array}$ & $\begin{array}{l}\text { A. urinae } \\
944-94\end{array}$ & $\begin{array}{l}\text { A. urinae } \\
998-93\end{array}$ & $\begin{array}{l}\text { A. urinae } \\
\text { G1-84 }\end{array}$ & P. urinaeequi & P. damnosus \\
\hline A. viridans & 100.00 & & & & & & & & \\
\hline A. urinae $\mathrm{E} 2^{\mathrm{T}}$ & 93.51 & 100.00 & & & & & & & \\
\hline A. urinae F1-84 & 92.93 & 99.32 & 100.00 & & & & & & \\
\hline A. urinae $1656-92$ & 93.67 & 99.33 & 98.82 & 100.00 & & & & & \\
\hline A. urinae $944-94$ & 92.77 & 98.30 & 97.76 & 98.98 & 100.00 & & & & \\
\hline A. urinae $998-93$ & 93.56 & 98.42 & 97.89 & 98.92 & 97.86 & 100.00 & & & \\
\hline A. urinae G1-84 & 92.64 & 98.24 & 97.57 & 97.82 & 96.75 & 98.06 & 100.00 & & \\
\hline P. urinaeequi & 99.56 & 93.54 & 92.94 & 93.72 & 92.77 & 93.88 & 92.98 & 100.00 & \\
\hline P. damnosus & 86.49 & 85.79 & 85.30 & 85.79 & 85.22 & 85.93 & 86.04 & 87.64 & 100.00 \\
\hline
\end{tabular}

\footnotetext{
"The sequence alignment was corrected for multiple base changes by the method of Jukes and Cantor (16).
} 


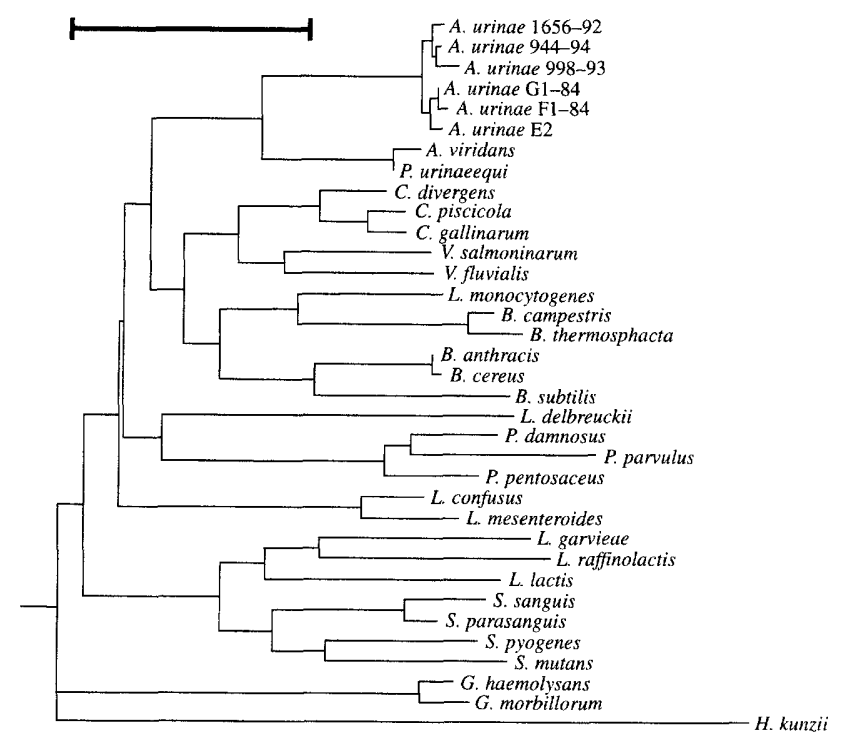

FIG. 1. Dendrogram based on an alignment of 1,320 nucleotides of the $16 \mathrm{~S}$ rRNA genes of $A$. urinae and other gram-positive, catalase-negative species. The tree was inferred from similarity values by using the neighbor-joining method of Saitou and Nei (17). The genus names, nucleotide sequence accession numbers, and designations of the strains used in this analysis are shown in Table 2. Scale bar $=5 \%$ difference in DNA sequence.

negative and esculin-positive strains and 3 nucleotide differences between the esculin-negative strains $A$. urinae F1-84 and G1-84. There were 88 to 92 nucleotide differences between two $A$. urinae strains $\left(1656-92\right.$ and $\left.\mathrm{E}^{\mathrm{T}}\right)$ and $A$. viridans. The $A$. urinae sequences were aligned with the sequences of 29 reference strains from 12 gram-positive, catalase-negative genera and formed a distinct group (Fig. 1). When $A$. urinae strains were compared to $A$. viridans, the levels of similarity were between 92.6 and $93.5 \%$. A viridans and $A$. urinae strains were on separate lines of descent. The sequence of $P$. urinaeequi was $99.6 \%$ similar to the sequence of $A$. viridans. $P$. urinaeequi was more closely related to $A$. viridans than to other Pediococcus spp.

\section{DISCUSSION}

The $A$. urinae strains that were initially isolated from human infections in Denmark have been shown to constitute a very homogeneous phenotypic group of bacteria (7). However, six of seven recent isolates received at the CDC Streptococcus Laboratory resembled $A$. urinae but were esculin hydrolysis positive and thus belonged to a new biotype. The ability to produce acid from maltose differed among both the esculinpositive strains and the esculin-negative strains. This phenotypic characteristic seems to be less reliable for identification, since $A$. urinae strains originally were described as maltose positive, which could not be confirmed for strains $\mathrm{E} 2^{\mathrm{T}}, \mathrm{G} 1-84$, and F1-84 in the present study. $A$. urinae strains may be separated easily from other catalase-negative, gram-positive cocci that divide in two planes by differences in major important tests for this group of bacteria (Table 5). For routine laboratory identification, the leucine aminopeptidase, pyrrolidonyl aminopeptidase, and vancomycin sensitivity tests are especially useful (14).

DNA-DNA relatedness criteria that should be considered essential for including strains in a species are a level of relatedness of $70 \%$ or greater under optimal conditions for DNA
TABLE 5. Phenotypic characteristics of catalase-negative, grampositive cocci that divide in two planes ${ }^{a}$

\begin{tabular}{lccccccccc}
\hline \multicolumn{1}{c}{ Taxon } & ESC & VAN & PYR & LAP & NACl & $10^{\circ} \mathrm{C}$ & $45^{\circ} \mathrm{C}$ & $\mathrm{Hem}$ \\
\hline $\begin{array}{l}\text { Aerococcus urinae } \\
\text { biotype 1 }\end{array}$ & - & $\mathrm{S}$ & - & + & + & - & + & $\alpha$ \\
$\begin{array}{l}\text { Aerococcus urinae } \\
\text { biotype 2 }\end{array}$ & + & $\mathrm{S}$ & - & + & + & - & + & $\alpha$ \\
Aerococcus viridans & & $\mathrm{S}$ & + & - & + & - & - & $\alpha$ \\
Pediococcus uninaeequi & & $\mathrm{S}$ & - & - & + & - & - & $\alpha$ \\
Alloiococcus otitidis & & $\mathrm{S}$ & + & + & + & - & - & $\mathrm{n}$ \\
Gemella spp. & & $\mathrm{S}$ & + & $\mathrm{v}$ & - & - & - & $\mathrm{n}$ \\
Helcococcus kunzii & & $\mathrm{S}$ & + & - & + & - & - & $\mathrm{n}$ \\
Pediococcus spp. & & $\mathrm{R}$ & - & + & $\mathrm{v}$ & - & $\mathrm{v}$ & $\alpha$ \\
Tetragenococcus & & $\mathrm{S}$ & - & + & + & + & - & $\alpha$
\end{tabular}

halophilus

"Abbreviations: ESC, esculin hydrolysis; VAN, vancomycin disk test; S, sensitive; R, resistant; PYR, pyrrolidonyl aminopeptidase; LAP, leucine aminopeptidase; $\mathrm{NACl}$, growth in broth containing $6.5 \% \mathrm{NaCl} ; 10^{\circ} \mathrm{C}$ and $45^{\circ} \mathrm{C}$, growth at 10 and $45^{\circ} \mathrm{C}$, respectively; Hem, hemolytic reaction on agar containing $5 \%$ sheep blood; $\alpha$, alpha-hemolytic; $n$, no hemolysis; $v$, variable.

reassociation and a level of divergence of less than $5 \%$ for related sequences (19). A level of relatedness of $60 \%$ or greater under stringent DNA reassociation conditions is also recommended for including strains in a species (3). Most of the esculin-negative strains fulfilled these criteria; the only exception was strain 998-93 (Table 3), which was borderline, as were four esculin-positive strains. When the esculin-positive strain 1656-92 was labeled, three of the esculin-positive strains fulfilled the criteria, whereas two strains were borderline. There appear to be at least three closely related hybridization groups which are not phenotypically distinct. We therefore do not now propose any additional subspecies or species. When more esculin-positive strains are available for study, they may be found to constitute a separate entity (either a biotype, a subspecies, or a new species). The levels of relatedness between $A$. urinae DNA and DNAs of $A$. viridans strains and $P$. urinaeequi were 10 to $14 \%$. There is no genetic definition of a genus, although an ideal genetic genus would be a group of phenotypically similar species that are 40 to $65 \%$ related (3).

On the basis of 16S rRNA sequence comparisons, both the esculin-negative strains examined by Aguirre and Collins (1) and the esculin-negative and esculin-positive strains examined in this study exhibited great similarity. The levels of sequence similarity between $A$. urinae and $A$. viridans are 92.6 to $94.5 \%$ (1) (Fig. 1 and Table 4). Although similar levels of sequence similarity are exhibited by species in different genera, there are many examples of species in the same genus that exhibit this level or lower levels of sequence similarity. For comparison, in the genera shown in Fig. 1, Carnobacterium piscicola is $96.2 \%$ similar to Carnobacterium divergens and $96.9 \%$ similar to Carnobacterium gallinarum; Streptococcus mutans is $93.2 \%$ similar to Streptococcus pyogenes and 88.9 and $89.6 \%$ similar to Streptococcus sanguis and Streptococcus parasanguis, respectively; and Bacillus anthracis is $99.8 \%$ similar to Bacillus cereus and 93.6\% similar to Bacillus subtilis. The topology of the dendrogram, with respect to branch lengths and node positions, indicates that the Aerococcus branch is not much different from the Vagococcus, Lactococcus, and Streptococcus branches. Based on the $16 \mathrm{~S}$ rRNA sequence analysis, it seems appropriate that $A$. urinae strains are included in the genus Aerococcus. There is no doubt from previous studies (10) and from the present study (Table 4 and Fig. 1) that $P$. urinaeequi belongs in the genus Aerococcus.

A. urinae strains are found in a constant but relatively low 
percentage of urine specimens $(0.8 \%)$ (5). These isolates have the pathogenic potential to cause urinary tract infections. Most patients have the classical symptoms of this disease, recurrent disease episodes occur, and the distribution (i.e., number of bacteria per milliliter, singly or in admixture with other bacteria) of $A$. urinae in urine specimens resembles the distribution observed with other established urinary tract pathogens, including Escherichia coli and Enterococcus faecalis $(5,7)$. A. urinae also has the ability to cause septicemia and endocarditis; in Denmark 20 cases of bacteremia or septicemia were documented from 1987 to 1994 (8). Nearly all of the patients from whom $A$. urinae strains are isolated (from either urinary tract specimens or blood cultures) have clinical signs of acute infection. Rarely, $A$. viridans may also cause urinary tract infections, septicemia, and endocarditis; however, in a large proportion of cases, $A$. viridans strains obtained from clinical specimens are without clinical significance.

With respect to phenotypic characteristics, DNA relatedness, 16S rRNA sequences, and clinical disease spectrum, $A$. urinae and $A$. viridans exhibit similarities but they certainly also have differences. Genotypically, $A$. urinae is somewhat heterogeneous and may contain two or more subspecies. The number of deviant strains recognized thus far is insufficient to draw firm conclusions concerning this possibility. The present taxonomic status of $A$. urinae at the species level and at the genus level seems appropriate pending further data.

\section{REFERENCES}

1. Aguirre, M., and M. D. Collins. 1992. Phylogenetic analysis of some Aerococcus-like organisms from urinary tract infections: description of Aerococcus urinae sp. nov. J. Gen. Microbiol. 138:401-405.

2. Bosley, G. S., P. L. Wallace, C. W. Moss, A. G. Steigerwalt, D. J. Brenner, J. M. Swenson, G. A. Hebert, and R. R. Facklam. 1990. Phenotypic characterization, cellular fatty acid composition, and DNA relatedness of aerococci and comparison to related genera. J. Clin. Microbiol. 28:416-421.

3. Brenner, D. J., A. C. McWhorter, J. K. L. Knutson, and A. G. Steigerwalt. 1982. Escherichia vulneris: a new species of Enterobacteriaceae associated with human wounds. J. Clin. Microbiol. 15:1133-1140.

4. Brosius, J., M. L. Palmer, J. P. Kennedy, and H. F. Noller. 1978. Complete nucleotide sequence of a $16 \mathrm{~S}$ ribosomal RNA gene from Escherichia coli. Proc. Natl. Acad. Sci. USA 75:4801-4805.

5. Christensen, J. J., B. Korner, and H. Kjaergaard. 1989. Aerococcus-like organisms-an unnoticed urinary tract pathogen. APMIS 97:539-546.

6. Christensen, J. J., E. Gutschik, A. Friis-Moeller, and B. Korner. 1991
Urosepticemia and fatal endocarditis caused by Aerococcus-like organisms. Scand. J. Infect. Dis. 23:717-721.

7. Christensen, J. J., H. Vibits, J. Ursing, and B. Korner. 1991. Aerococcus-like organism, a newly recognized potential urinary tract pathogen. J. Clin. Microbiol. 29:1049-1053.

8. Christensen, J. J., I. P. Jensen, J. Faerk, B. Kristensen, R. Skov, B. Korner, and The Danish ALO Study Group. 1995. Bacteremia/septicemia due to Aerococcus-like organisms: report of seventeen cases. Clin. Infect. Dis. 21: 943-947.

9. Collins, M. D., R. R. Facklam, U. M. Rodrigues, and K. L. Ruoff. 1993. Phylogenetic analysis of some Aerococcus-like organisms from clinical sources: description of Helcococcus kunzii gen. nov., sp. nov. Int. J. Syst. Bacteriol. 43:425-429.

10. Collins, M. D., A. M. Williams, and S. Wallbanks. 1990. The phylogeny of Aerococcus and Pediococcus as determined by $16 \mathrm{~S}$ rRNA sequence analysis: description of Tetragenococcus gen. nov. FEMS Microbiol. Lett. 70:255-262.

11. Daly, J. S., M. G. Worthington, D. J. Brenner, C. W. Moss, D. G. Hollis, R. S Weyant, A. G. Steigerwalt, R. E. Weaver, M. I. Daneshvar, and S. P O'Connor. 1993. Rochalimaea elizabethae sp. nov. isolated from a patient with endocarditis. J. Clin. Microbiol. 31:872-881.

12. Devereux, J., P. Haeberli, and O. Smithies. 1984. A comprehensive set of sequence analysis programs for the VAX. Nucleic Acids Res. 12:387-395.

13. Facklam, R., and J. A. Elliott. Identification, classification, and clinical relevance of catalase negative, gram-positive cocci, excluding the streptococci and enterococci. Clin. Microbiol. Rev. 8:479-495.

14. Facklam, R., N. Pigott, R. Franklin, and J. Elliott. 1995. Evaluation of three disk tests for identification of enterococci, leuconostocs, and pediococci. J. Clin. Microbiol. 33:885-887.

15. Felsenstein, J. 1993. PHYLIP-phylogeny inference package, version 3.51c University of Washington, Seattle.

16. Jukes, T. H., and C. R. Cantor. 1969. Evolution of protein molecules, p. 21-132. In H. N. Munro (ed.), Mammalian protein metabolism, vol. 3. Academic Press, Inc., New York, N.Y.

17. Saitou, N., and M. Nei. 1987. The neighbor-joining method: a new method for reconstructing phylogenetic trees. Mol. Biol. Evol. 4:406-425.

18. Stackebrandt, E., and O. Charfreitag. 1990. Partial 16S rRNA primary structure of five Actinomyces species: phylogenetic implications and development of an Actinomyces israelii-specific oligonucleotide probe. J. Gen. Microbiol. 136:37-43.

19. Wayne, L. G., D. J. Brenner, R. R. Colwell, P. A. D. Grimont, O. Kandler, M. I. Krichevsky, L. H. Moore, W. E. C. Moore, R. G. E. Murray, E. Stackebrandt, M. P. Starr, and H. G. Trüper, 1987. Report of the Ad Hoc Committee on Reconciliation of Approaches to Bacterial Systematics. Int. J. Syst. Bacteriol. 37:463-464.

20. Weisburg, W. G., S. M. Barns, D. A. Pelletier, and D. J. Lane. 1991. 16S ribosomal DNA amplification for phylogenetic study. J. Bacteriol. 173:697703.

21. Whitney, A. M., and S. P. O'Connor. 1993. Phylogenetic relationship of Gemella morbillorum to Gemella haemolysans. Int. J. Syst. Bacteriol. 43:832838 . 